\title{
Tingkat Inflasi, Tingkat Bunga SBI, dan Nilai Tukar Rupiah terhadap Pengaruh Indeks Harga Saham
}

\author{
Yurniwati \\ Universitas Andalas, Indonesia \\ Yurniwati.fekom.unand@gmail.com
}

\author{
Lenny Wahyuni \\ Universitas Andalas, Indonesia \\ Lennywahyuni91@gmail.com
}

Corresponding Author : Yurniwati

Submitted: 3 Juli 2020

Accepted: 1 Agustus 2020

Published: 1 Agustus 2020

\begin{abstract}
ABSTRAK
Fluktuasi di pasar saham dapat dilihat dengan memperhatikan nilai saham di pasar. Perubahan nilai saham yang disebabkan oleh aktivitas perdagangan akan membentuk indeks nilai saham. Penelitian ini untuk menguji pengaruh tingkat inflasi, suku bunga SBI, dan nilai tukar rupiah terhadap dolar AS dalam indeks harga saham sektor pertanian selama periode 2010-2014. Metode yang digunakan dalam penelitian ini menggunakan analisis regresi berganda. Penelitian ini menggunakan data sekunder. Penarikan sampel penelitian dengan metode purposive sampling yaitu: penarikan sampel dengan kriteria tertentu. Data historis diambil dari Laporan Statistik Ekonomi Keuangan Indonesia 1, Laporan Tahunan Bursa Efek Indonesia, dan laporan bulanan Bank Indonesia. Hasil penelitian menyimpulkan bahwa variabel tingkat inflasi, suku bunga SBI, dan nilai tukar dolar AS tidak berpengaruh pada indeks harga saham sektor pertanian. Pengujian bersama juga menunjukkan bahwa tiga variabel independen tidak mempengaruhi indeks harga saham sektor pertanian. Untuk penelitian selanjutnya disarankan menambah variabel independen penelitian agar bisa lebih menggambarkan faktor yang mempengaruhi indeks harga saham dipasar modal indonesia.

Kata kunci: Tingkat Inflasi, Suku Bunga SBI, Nilai Tukar, Indeks Harga Saham Sektor Pertanian.

\section{PENDAHULUAN}

Indeks harga saham adalah salah satu indikator yang digunakan untuk mengukur pergerakan pasar modal di Indonesia. Di bursa efek, indeks harga saham tidak selalu tetap, kadang meningkat dan kadang juga menurun, tergantung pada kekuatan permintaan dan penawaran. Perbedaan persepsi yang dimiliki oleh investor pergerakan harga saham sesuai dengan informasi yang dimiliki. Pergerakan indeks harga saham memberikan petunjuk tentang

kenaikan dan penurunan kegiatan pasar modal dan investor dalam membeli dan menjual saham. Ada dua faktor yang mempengaruhi harga saham, (1) faktor internal yang berkaitan dengan kondisi fundamental perusahaan, dilihat dari laporan keuangan dan (2) faktor eksternal yang terkait dengan fundamental ekonomi makro, misalnya Produk Domestik Bruto (PDB), tingkat inflasi, bunga menilai situasi sosial dan politik dan sebagainya, (Kewal, 2012).
\end{abstract}


Faktor ekonomi makro yang mempengaruhi fluktuasi harga sahamtermasuk inflasi, suku bunga SBI, dan nilai tukar dolar AS. Inflasi ditandai oleh kenaikan harga barang secara umum dan terus-menerus dalam arti tidak hanya sesaat. Terjadinya inflasi menyebabkan peningkatan biaya produksi seperti biaya bahan baku dan tenaga kerja. Selain itu, inflasi juga mendorong turunnya daya beli rupiah, yang mengakibatkan perusahaan tidak berani menaikkan harga produk terlalu tinggi. Peningkatan biaya produksi yang lebih tinggi daripada kenaikan harga jual produk akan mengurangi laba perusahaan untuk membayar dividen yang juga akan berdampak pada penurunan indeks harga saham, (Maryanti, 2009).

Suku bunga Sertifikat Bank Indonesia (SBI) dapat mempengaruhi suku bunga umum yang berlaku di pasar uang, termasuk suku bunga deposito, yang merupakan alternatif bagi investor untuk menginvestasikan modalnya. Jika suku bunga SBI ditetapkan naik, investor akan mendapatkan pengembalian yang lebih besar pada suku bunga deposito yang diinvestasikan sehingga investor akan cenderung untuk menyetor modal mereka daripada berinvestasi di saham. Selain itu, nilai tukar dalam hal ini dolar AS juga mempengaruhi indeks harga saham. Penurunan nilai tukar rupiah juga dapat memengaruhi pilihan investor untuk menginvestasikan dana dalam bentuk dolar dengan harapan memperoleh keuntungan dari selisih nilai tukar. Depresiasi rupiah juga dapat mempengaruhi aktivitas perusahaan yang mengimpor bahan baku dari luar negeri dan memiliki utang luar negeri dalam bentuk valuta asing, (Haryogo, 2013).

Salah satu indeks sektor utama yang dimiliki oleh BEI adalah indeks sektor pertanian. Sektor pertanian adalah sektor yang memainkan peran penting dalam perekonomian nasionalkarena menyerap banyak tenaga kerja. Banyak orang Indonesia menggantungkan hidupnya pada sektor ini, baik secara langsung maupun tidak langsung. Sektor ini juga merupakan sektor utama bagi banyak sektor, karena tidak sedikit hasil yang dihasilkan oleh sektor pertanian juga dibutuhkan oleh sektor lain.Selain itu, Indonesia adalah negara yang kaya akan sumber daya alam yang merupakan salah satu aset bangsa untuk membantu pembangunan ekonomi. 14,4\% dari PDB Indonesia pada tahun 2012 berasal dari sektor pertanian melalui penyediaan makanan dan bahan baku industri, ditambah dengan kegiatan ekspor (Nugrayasa, 2013).

Sebuah studi empiris yang menganalisis pengaruh variabel ekonomi makro terhadap indeks harga saham telah dilakukan oleh para peneliti termasuk; (Maryanti, 2009), (Kewal, 2012), dan (Haryogo, 2013). Pada penelitian ini membutuhkan studi mendalam tentang pengaruh variabel makro terhadap indeks harga saham.

\section{STUDI TEORI DAN HIPOTESIS}

Teori pemegang saham menjelaskan hubungan antara manajemen perusahaan dan pemegang saham. Teori ini bertujuan membantu manajemen perusahaan dalam meningkatkan penciptaan nilai sebagai hasil dari kegiatan yang mereka lakukan dan meminimalkan kerugian yang mungkin timbul bagi pemegang saham mereka. Dalam menciptakan nilai bagi perusahaan, manajemen harus mampu mengelola semua sumber daya perusahaan. Sumber daya perusahaan terdiri dari karyawan (modal manusia), aset fisik (modal fisik), dan modal struktural (modal struktural). Jika semua sumber daya perusahaan dapat dikelola dan digunakan dengan benar, itu akan menciptakan nilai tambah bagi perusahaan sehingga dapat meningkatkan kinerja keuangan perusahaan dan pemegang saham.

Teori investasi menjelaskan keputusan investasi selalu melibatkan dua hal, yaitu risiko dan pengembalian. Risiko memiliki hubungan positif dan linier dengan 
pengembalian investasi yang diharapkan, sehingga semakin besar pengembalian yang diharapkan, semakin besar pula risiko yang harus ditanggung oleh seorang investor. Pengembalian yang diperoleh dari investasi saham berasal dari dua sumber, yaitu dividen dan capital gain, sementara risiko investasi tercermin dalam variabilitas pengembalian saham yang diperoleh atau risikonya juga sama dengan perbedaan antara pengembalian yang diharapkan dan pengembalian aktual (Wijayanti, 2013).

Teori portofolio saham adalah bagaimana memilih kombinasi jenis-jenis saham yang akan dipegang oleh investor untuk memperoleh tingkat pengembalian tertinggi dengan risiko terendah dan sebaliknya. Tujuan pembentukan portofolio saham adalah untuk menyebarkan risiko atau mendiversifikasi risiko yang mungkin dihadapi investor dari masing-masing aset investasi mereka. Risiko dalam berinvestasi memiliki dua karakteristik; risiko yang terdiversifikasi adalah risiko yang dapat dihilangkan atau dihindari dengan melakukan diversifikasi dengan membentuk portofolio, dan risiko yang tidak terdiversifikasi adalah risiko yang tidak dapat dihilangkan dengan melakukan diversifikasi karena risiko ini telah mempengaruhi semua perusahaan atau saham di bursa sehingga menginvestasikan dana dalam berbagai jenis saham tidak dapat menghilangkan jenis risiko ini.

Pasar modal memiliki peran besar bagi perekonomian suatu negara karena pasar modal melakukan dua fungsi sekaligus, yaitu fungsi ekonomi dan fungsi keuangan (Husnan, 2003). Fungsi ekonomi karena menyediakan fasilitas atau kendaraan yang menyatukan dua kepentingan, yaitu mereka yang memiliki kelebihan dana (investor) dan mereka yang membutuhkan dana (emiten). Fungsi keuangan sedangka karena pasar modal memberikan kemungkinan dan peluang untuk memperoleh pengembalian (return) bagi pemilik dana, sesuai dengan karakteristik investasi yang dipilih.
Inflasi adalah gejala kenaikan harga barang yang bersifat umum dan berkelanjutan (Manurung, 2005). Peningkatan harga suatu barang dapat dikatakan sebagai gejala inflasi jika kenaikan harga barang dapat memicu kenaikan harga barang secara umum dan terus menerus dalam arti tidak hanya sesaat. Faktor-faktor yang menyebabkan inflasi dibagi menjadi dua: inflasi tarikan permintaan dan inflasi cost push (Sukirno, 2002). Permintaan tarikan inflasi terjadi ketika sektor perusahaan tidak dapat dengan cepat melayani permintaan publik di pasar. Masalah kurangnya barang akan berlaku dan ini akan menyebabkan kenaikan harga. Sementara itu, inflasi tekanan biaya terjadi ketika kenaikan harga dalam perekonomian disebabkan oleh kenaikan biaya produksi.

Sertifikat Bank Indonesia (SBI), pada prinsipnya, adalah surat berharga berdenominasi rupiah yang dikeluarkan oleh sistem diskonto oleh Bank Sentral Indonesia sebagai pengakuan atas hutang jangka pendek. Tujuannya adalah sebagai alat kontrol moneter melalui operasi pasar terbuka (Darmawi, 2005). Sementara itu, suku bunga SBI adalah nilai yang harus dibayar oleh Bank Indonesia kepada investor untuk surat berharga jangka pendek yang diterbitkan oleh Bank Indonesia, yang jumlahnya ditentukan oleh mekanisme pasar berdasarkan sistem lelang.

Peningkatan suku bunga akan meningkatkan beban bunga emiten, sehingga keuntungan bisa dipotong. Dengan penurunan laba, investor akan memiliki sentimen negatif terhadap perusahaan sehingga akan berdampak pada penurunan harga saham perusahaan yang bersangkutan. Selain itu, ketika suku bunga tinggi, biaya produksi akan meningkat dan harga produk akan lebih mahal sehingga konsumen dapat menunda pembelian dan menyimpan dana mereka di bank. Akibatnya, penjualan perusahaan menurun. Penurunan penjualan dan laba perusahaan 
akan menekan harga saham (Mansur, 2009).

Nilai tukar adalah alat perbandingan nilai tukar mata uang suatu negara dengan mata uang negara asing atau perbandingan nilai tukar antar negara (Hasibuan, 2009). Nilai mata uang yang tinggi mendorong investor untuk berinvestasi di pasar uang. Hal ini disebabkan tingginya harga mata uang asing yang menyebabkan perdagangan di BEI akan semakin lamban, dan sebaliknya penurunan mata uang mendorong investor untuk berinvestasi di pasar modal sehingga harga saham akan naik, (Maryanti, 2009), (Kewal, 2012), dan (Haryogo, 2013).

Melemahnya nilai tukar rupiah secara signifikan dapat memengaruhi tingkat pengembalian investasi suatu perusahaan, terutama perusahaan yang hanya mengandalkan bahan baku dari luar negeri dan perusahaan yang hanya mengandalkan pinjaman luar negeri dalam dolar AS untuk membiayai operasi perusahaan. Jadi depresiasi rupiah akan menyebabkan biaya yang harus ditanggung oleh perusahaan akan semakin besar sehingga akan mengurangi tingkat keuntungan yang didapat oleh perusahaan, dan ini akan dapat mengurangi harga saham perusahaan yang diperdagangkan di pasar modal, (Maryanti, 2009), (Kewal, 2012), (Haryogo, 2013).

Salah satu yang harus diketahui oleh calon investor sebelum berinvestasi di pasar modal adalah indeks harga saham sebagai cerminan dari pergerakan harga saham. Calon investor dapat membuat informasi historis tentang harga dan volume perdagangan saham yang bersangkutan sebagai dasar untuk peramalan dalam menentukan pergerakan harga saham selanjutnya. Banyaknya transaksi jual beli saham di lantai bursa menyebabkan pergerakan harga saham yang begitu cepat pada setiap hari perdagangan, (Maryanti, 2009).

Kecenderungan pergerakan harga saham yang bergerak dari bawah ke atas disebut bullish, sedangkan kecenderungan pergerakan harga saham dari atas ke bawah disebut bearish. Perubahan harga saham yang terjadi akibat aktivitas jual beli akan membentuk indeks harga saham. Indeks harga saham yang digunakan dalam penelitian ini adalah indeks harga saham sektor pertanian yang merupakan salah satu sektor utama di BEI. Adanya kegiatan utama yang berbeda dari sektor lain tentunya akan mempengaruhi respon sektor pertanian dalam merespon perubahan berbagai faktor makroekonomi, (Hasibuan, 2009).

Studi lain juga dilakukan oleh Maryanti menemukan bahwa suku bunga SBI dan nilai tukar memiliki efek negatif pada CSPI (Maryanti, 2009). Kemudian (Thobarry, 2009) menemukan bahwa nilai tukar memiliki efek positif yang signifikan dan variabel inflasi memiliki efek negatif yang signifikan terhadap indeks harga saham sektor properti, sedangkan variabel tingkat bunga dan pertumbuhan PDB hanya signifikan ketika diuji secara bersamaan dan tidak memiliki efek signifikan ketika diuji secara parsial. Hasil studi (Kewal, 2012) menunjukkan bahwa inflasi, suku bunga SBI dan pertumbuhan PDB tidak memiliki pengaruh yang signifikan terhadap CSPI, sedangkan nilai tukar rupiah memiliki efek negatif dan signifikan terhadap CSPI.

Hipotesis penelitian 1 adalahtingkat inflasi memiliki efek negatif pada indeks harga saham sektor pertanian. Ini didasarkan pada temuan tingkat bunga SBI, nilai tukar dolar AS, dan tingkat inflasi yang memiliki efek negatif pada CSPI (Maryanti, 2009), inflasi memiliki pengaruh positif yang signifikan terhadap indeks harga saham properti sektor (Thobarry, 2009) Tingkat inflasi, suku bunga SBI dan pertumbuhan PDB tidak memiliki pengaruh yang signifikan terhadap CSPI (Kewal, 2012).

Hipotesis 2 adalah bahwa suku bunga SBI memiliki efek negatif pada indeks harga saham sektor pertanian. Hal ini berdasarkan hasil penelitian pada suku 
bunga SBI yang berpengaruh negatif terhadap CSPI (Maryanti, 2009), suku bunga tidak mempengaruhi indeks harga saham (Thobarry, 2009), suku bunga SBI tidak berpengaruh terhadap (IHSG (Kewal, 2012) dan hipotesis 3 adalah nilai tukar dolar AS memiliki efek negatif pada indeks harga saham sektor pertanian.

\section{METODE PENELITIAN}

\subsection{Populasi dan sampel.}

Data yang digunakan dalam penelitian ini adalah data sekunder yang diperoleh dari indeks harga saham sektor pertanian pada tahun 2010 hingga 2014 yang dikumpulkan melalui situs web Bursa Efek Indonesia yang dikenal sebagai laporan statistik tahunan Bursa Efek Indonesia dan informasi tentang tingkat inflasi, suku bunga SBI, dan nilai tukar dolar AS yang diperoleh dari Laporan Statistik Ekonomi Keuangan Indonesia, yang diterbitkan setiap bulan oleh Bank Indonesia.

\subsection{Metode penarikan sampel.}

Metode yang digunakan dalam penarikan sampel adalah purposive sumpling.

\subsection{Devinisi operasional.}

Penelitian ini adalah studi verifikasi yang bertujuan untuk menguji pengaruh variabel independen, yaitu tingkat inflasi, Inflasi adalah gejala kenaikan harga barang yang bersifat umum dan berkelanjutan (Manurung, 2005). Tingkat bunga SBI nilai yang harus dibayar oleh Bank Indonesia kepada investor untuk surat berharga jangka pendek yang diterbitkan oleh Bank Indonesia, yang jumlahnya ditentukan oleh mekanisme pasar berdasarkan sistem lelang, (Darmawi, 2005). Nilai tukar adalah alat perbandingan nilai tukar mata uang suatu negara dengan mata uang negara asing atau perbandingan nilai tukar antar negara, (Hasibuan, 2009). Nilai tukar dolar AS pada variabel dependen dari indeks harga saham sektor pertanian di BEI.

\subsection{Metode analisis}

Metode analisis yang digunakan dalam penelitian ini adalah metode regresi linier berganda yang menunjukkan arah pengaruh tingkat inflasi, suku bunga SBI, dan nilai tukar dolar AS terhadap indeks harga saham sektor pertanian. Untuk melakukan pengujian hipotesis analisis regresi digunakan melalui pengujian parsial dengan uji t dan pengujian simultan dengan uji F. Dalam penggunaan analisis regresi, untuk menunjukkan hubungan yang valid atau tidak memihak perlu untuk menguji asumsi klasik pada model regresi yang digunakan. Tujuan lain adalah untuk memastikan bahwa model regresi yang digunakan memiliki data yang terdistribusi normal, bebas dari gejala multikolinieritas, dan heteroskedastisitas. Koefisien determinasi pada dasarnya mengukur seberapa jauh kemampuan model untuk menjelaskan variasi variabel independen (Ghozali, 2013).

\section{HASIL PENELITIAN}

\subsection{Hasil Pengujian Asumsi Klasik}

Uji normalitas data, dilakukan dengan menggunakan uji One KolmogorovSmirnov dari nilai residu yang tidak standar dari model yang diteliti. Dalam hasil uji Kolmogorov Smirnov bahwa nilai signifikansi masing-masing variabel lebih besar dari 0,05 . Ini membuktikan bahwa data yang digunakan dalam regresi berdistribusi normal (Ghozali, 2013).

Selanjutnya, uji multikolinieritas, berdasarkan pada nilai toleransi dan VIF menunjukkan bahwa tidak ada nilai toleransi dari variabel independen di bawah 0,1 serta tidak ada nilai VIF di atas 10 , sehingga telah terbukti bahwa tidak ada multikolinieritas (Ghozali, 2013).

Dari uji heteroskedastisitas yang dilakukan dengan melihat grafik Scatterplot yang diperoleh setelah data diproses melalui SPSS, dapat dilihat bahwa titik-titik data tersebar secara acak dan tersebar di atas atau di bawah sumbu nol Y. Ini berarti 
tidak ada heteroskedastisitas dalam model regresi (Ghozali, 2013).

\subsection{Hasil Pengujian Hipotesis \\ 4.2.1. Hasil uji koefesien determinasi}

Dari nilai koefisien determinasi dapat dijelaskan bahwa variabel dependen $0,6 \%$ dari indeks harga saham sektor pertanian dapat dijelaskan oleh variabel independen tingkat inflasi, suku bunga SBI, dan nilai tukar dolar AS. Sedangkan sisanya 99,4\% dijelaskan oleh faktor atau variabel lain yang tidak termasuk dalam model penelitian ini.

\subsubsection{Hasil uji secara simultan.}

Dari uji $\mathrm{F}$ diperoleh nilai signifikansi 0,351 . Karena nilai signifikansi lebih besar dari 0,05 , dapat diartikan bahwa tingkat inflasi, tingkat bunga SBI, dan nilai tukar dolar AS bersama-sama tidak mempengaruhi indeks harga saham sektor pertanian. Hasil uji $\mathrm{F}$ menunjukkan tidak ada pengaruh tingkat inflasi, suku bunga SBI, dan nilai tukar dolar AS secara bersamaan pada indeks harga saham sektor pertanian. Tiga variabel yang dipelajari bersama tidak mempengaruhi keputusan investor untuk berinvestasi di sektor pertanian. Ini membuktikan bahwa variabel tingkat inflasi, tingkat bunga SBI, dan nilai tukar dolar AS bersama-sama tidak dapat digunakan untuk memprediksi nilai indeks harga saham sektor pertanian karena tidak mempengaruhi perubahan dan pergerakan harga saham.Investor masih lebih cenderung menunggu dan mengamati faktor-faktor lain dalam agregat atau secara bersamaan kemudian investor membuat keputusan mengenai investasi dalam saham di sektor pertanian.

\subsubsection{Hasil uji t}

1. Variabel tingkat inflasi menghasilkan $t$ hitung $-1,773$ sedangkan t meja pada tingkat kepercayaan $95 \%$ adalah -2.007 . Karena thitung $>\mathrm{t}$ tabel berarti bahwa faktor tingkat inflasi tidak mempengaruhi indeks harga saham sektor pertanian.

2. Variabel suku bunga SBI menghasilkan t-hitung $-0,358$ sedangkan $t$ tabel pada tingkat kepercayaan 95\% adalah -2,007. Karena thitung> ttabel berarti bahwa suku bunga SBI tidak berpengaruh pada indeks harga saham sektor pertanian

3. Variabel nilai tukar dolar AS menghasilkan pada hitungan 0,249 sedangkan $t$ tabel pada tingkat kepercayaan 95\% adalah -2,007. Karena thitung> ttabel berarti bahwa nilai tukar dolar AS tidak berpengaruh pada indeks harga saham sektor pertanian.

Dari tabel 1 di atas dapat disusun beberapa persamaan regresi sebagai berikut:

$\mathrm{Y}=-2.129-4136.629 \times 1-3561.302 \times 2+$ $0,022 \times 3+\mathrm{e}$

Dari persamaan regresi di atas, dapat diartikan sebagai berikut:

Nilai konstanta menunjukkan angka 2.129 yang negatif. Ini dapat ditafsirkan bahwa jika perubahan dalam variabel tingkat inflasi, suku bunga SBI, dan nilai tukar dolar AS dianggap konstan, maka nilai indeks harga saham sektor pertanian mencapai -2.129.

Tingkat Inflasi (X1) menunjukkan angka -4136.629 berarti bahwa jika suku bunga SBI dan nilai tukar dolar AS konstan maka peningkatan inflasi diikuti oleh penurunan indeks harga saham sektor pertanian. Suku bunga SBI (X2) menunjukkan angka tersebut-3561.302 berarti bahwa jika inflasi, nilai tukar dolar AS konstan, maka setiap kenaikan suku bunga SBI akan mengurangi indeks harga saham sektor pertanian.

Nilai tukar dolar AS (X3) menunjukkan angka 0,022 yang berarti bahwa jika tingkat inflasi dan suku bunga SBI konstan maka setiap kenaikan nilai tukar dolar AS akan meningkatkan indeks harga saham sektor pertanian. 


\subsection{Analisis dan Diskusi}

Hasil pengujian menyatakan bahwa tingkat inflasi tidak mempengaruhi indeks harga saham sektor pertanian. Pada periode studi tingkat inflasi tidak secara langsung mempengaruhi keputusan investor untuk berinvestasi di sektor pertanian. Indeks harga saham sektor pertanian sangat dipengaruhi oleh harga saham sub-sektor perkebunan karena sekitar 16 dari 21 perusahaan yang terdaftar di sektor pertanian berasal dari sub-sektor perkebunan. Output produksi terbesar dari sub-sektor perkebunan adalah Crude Palm Oil (CPO) atau minyak sawit mentah. Sedangkan inflasi mempengaruhi kenaikan harga barang secara umum di pasar. Barang yang dimaksud adalah barang yang langsung dikonsumsi oleh masyarakat umum.

Selain itu, beberapa investor lebih suka menjadi pedagang. Melalui investasi jangka pendek, investor dapat membeli dan menjual saham kapan saja untuk mendapatkan keuntungan yang lebih besar melalui capital gain, yaitu selisih antara harga jual dengan harga beli saham dan dapat membuat keputusan untuk membeli atau menjual saham sebelum gejala inflasi terjadi.

Hasil penelitian ini mendukung penelitian yang dilakukan oleh (Safitri, 2014) yang menemukan bahwa inflasi tidak berpengaruh signifikan terhadap indeks harga saham sektor perkebunan. Hasil serupa juga ditemukan oleh (Amin, 2012), (Kewal, 2012), dan (Lawrence, 2013) yaitu inflasi tidak mempengaruhi IHSG. Namun, hasil yang diperoleh berbeda dengan hasil penelitian yang dilakukan oleh (Thobarry, 2009) yang dalam penelitiannya menemukan bahwa inflasi memiliki pengaruh negatif dan signifikan terhadap indeks harga saham sektor properti.

Hasil pengujian dinyatakan bahwa suku bunga SBI juga tidak mempengaruhi indeks harga saham sektor pertanian. Ini bisa dilihat ketika kenaikan suku bunga SBI kurang mempengaruhi tingkat minat investor untuk berinvestasi di sektor pertanian. Dalam membuat keputusan investasi di sektor pertanian, investor cenderung memperhatikan perubahan harga komoditas CPO sebagai salah satu komoditas ekspor utama sektor pertanian. Investor juga akan memperhatikan faktorfaktor lain seperti cuaca, bencana alam, penangkapan ikan ilegal, dan faktor alam lainnya yang dapat mempengaruhi aktivitas sektor pertanian.

Selain itu, investor di Indonesia termasuk di antara jenis investor yang suka melakukan transaksi saham jangka pendek atau pedagang, sehingga mereka cenderung mengambil tindakan mengambil keuntungan dengan harapan mendapatkan capital gain tinggi di pasar modal dibandingkan dengan berinvestasi di SBI . Keberadaan perusahaan yang memberikan dividen yang cukup tinggi kepada pemegang saham mereka juga merupakan faktor pendorong investor untuk berinvestasi di pasar saham, terutama sektor pertanian dibandingkan dengan berinvestasi pada sekuritas di pasar uang, (Kewal, 2012).

Hasil penelitian ini didukung oleh penelitian yang dilakukan oleh (Safitri, 2014) yang menemukan bahwa suku bunga tidak secara signifikan mempengaruhi indeks harga saham sektor perkebunan. Hasil serupa juga diperoleh oleh (Silim, 2013) dan (Kewal, 2012) yang menyatakan bahwa suku bunga SBI tidak berpengaruh signifikan pada CSPI.Namun, hasil yang diperoleh berbeda dari hasil penelitian yang dilakukan oleh (Liauw, 2011) dan (Wijayanti, 2013) yang menyatakan bahwa suku bunga SBI memiliki pengaruh negatif yang signifikan terhadap CSPI.

Hasil tes menyatakan bahwa kenaikan nilai tukar dolar AS berdampak kurang pada pemegang saham di sektor pertanian. Meskipun Indonesia menganut kebijakan nilai tukar mengambang bebas, Bank Indonesia sebagai otoritas moneter tidak membiarkan nilai tukar rupiah bergerak terlalu fluktuatif. Menurut Bank Indonesia, 
sebagaimana diatur dalam Undang-undang nomor 6 tahun 2009 yang mengatur Bank Indonesia (BI), salah satu fungsi BI adalah untuk mengatur dan memelihara sistem pembayaran yang lancar, BI memiliki hak untuk mengelola mata uang rupiah. Untuk menjaga stabilitas nilai tukar, BI pada waktu-waktu tertentu melakukan sterilisasi di pasar valuta asing, terutama ketika volatilitas nilai tukar yang berlebihan terjadi (bi.go.td, 2014). Oleh karena itu nilai tukar rupiah terhadap USD tidak signifikan dalam mempengaruhi indeks harga saham.

Hasil penelitian ini mendukung penelitian yang dilakukan oleh (Haryogo, 2013) bahwa nilai tukar tidak berpengaruh terhadap IHSG dan (Rahmanely, 2007) yang menemukan bahwa nilai tukar mata uang asing tidak berpengaruh signifikan terhadap pengembalian saham. Namun, hasil yang diperoleh berbeda dari hasil penelitian yang dilakukan oleh (Amin, 2012), (Kewal, 2012), dan (Wijayanti, 2013) yang menyatakan bahwa nilai tukar dolar AS memiliki pengaruh negatif yang signifikan terhadap CSPI dan (Thobarry, 2009) yang dalam penelitiannya menemukan bahwa nilai tukar dolar terhadap rupiah memiliki pengaruh positif dan signifikan terhadap indeks harga saham sektor Properti.

\section{KESIMPULAN}

Hasil penelitian menyimpulkan bahwa variabel tingkat inflasi, suku bunga SBI, dan nilai tukar dolar AS tidak berpengaruh pada indeks harga saham sektor pertanian. Pengujian bersama juga menunjukkan bahwa tiga variabel independen tidak mempengaruhi indeks harga saham sektor pertanian.

Terkait dengan temuan penelitian ini, Investor diharapkan lebih memperhatikan perubahan harga komoditas CPO sebagai komoditas ekspor utama yang diproduksi di sub-sektor perkebunan, kegiatan penangkapan ikan ilegal yang dapat mempengaruhi sub-sektor perikanan, serta kondisi alam seperti cuaca dan bencana alam yang terjadi. dapat mempengaruhi kegiatan di sektor pertanian dalam membuat kebijakan investasi di sektor pertanian. Selain itu, dari aspek internal atau fundamental perusahaan juga dapat digabungkan untuk digunakan dalam memprediksi pergerakan indeks harga saham sektor pertanian. Sehingga prediksi ini dapat membantu investor membuat keputusan yang tepat mengenai investasi mereka.

Keterbatasan penelitian ini masih terbatasnya variabel independen yang digunakan sehingga masih kurang maksimal hasil yang diharapkan dalam menggambarkan bagaimana tingkat inflasi, suku bunga dan nilai tukar mempengaruhi indeks harga saham sektor pertanian, disarankan agar peneliti selanjutnya diharapkan menganalisis faktor-faktor yang mempengaruhi indeks harga saham dari aspek internal atau fundamental perusahaan, seperti laba, rugi, dan faktor lain sehingga dihasilkan analisis. bisa lebih komprehensif dan seimbang. Selain itu, peneliti lain disarankan untuk memeriksa pengaruh ekonomi makro terhadap saham sektor lain dan memperpanjang periode studi sehingga indeks harga saham yang sektornya tahan dan rentan terhadap kondisi ekonomi makro yang tidak stabil dapat dipilih

\section{REFERENSI.}

Amin, M. Z. 2012. "Pengaruh Tingkat Inflasi, Suku Bunga SBI, Kurs Dolar (USD / IDR), dan Indeks Dow Jones (DJIA) menuju Pergerakan Indeks Harga persediaan Dikombinasikan di Bursa Efek Indonesia (BEI).", Fakultas Ekonomi Bisnis, Brawijaya, Malang.

Bank Indonesia. 2008. Surat Bank Indonesia No.10 / 1 / DPM / 2008 tentang Penerbitan Sertifikat Bank Lelang Melalui Indonesia. Jakarta. 
Bank Indonesia. 2010. Laporan Statistik Ekonomi Keuangan Indonesia. Jakarta: BI.

Bank Indonesia. 2011. Laporan Statistik Ekonomi Keuangan Indonesia. Jakarta: BI.

Bank Indonesia. 2012. Laporan Statistik Ekonomi Keuangan Indonesia. Jakarta: BI.

Bank Indonesia. 2013. Laporan Statistik Ekonomi Keuangan Indonesia. Jakarta: BI.

Bank Indonesia. 2014. Laporan Statistik Ekonomi Keuangan Indonesia. Jakarta: BI.Darmawi, H. 2005.

Pasar Keuangan Dan lembaga keuangan. Jakarta: Literasi Bumi.

Badan Pusat Statistik. 2010. Data PDB Indonesia. Jakarta: BPS.

Ghozali, I. 2013. Analisis Aplikasi Multivarian dengan Program

SPSS. Semarang Agen Penerbit Universitas Diponegoro.

Haryogo, A. 2013. "Pengaruh Nilai Tukar dan Indeks Dow Jones ttatap muka Gabungan Indeks di Bursa Efek Indonesia". Jurnal Finesta, Vol. Vol. 1, No. 1, 2013, hlm: 16.

Hasibuan, A. T. 2009. "Nilai Tukar Indeks Mata Uang dan Indeks Harga Saham Global melawan CSPI.", Pascasarjana USU: Medan., Medan.

Husnan, S. 2003. Dasar-Dasar Portofolio

$$
\begin{array}{ll}
\text { dan Analisis Efek. } \\
\text { Yogyakarta: UPP-AMP } \\
\text { YKPN. }
\end{array}
$$

Kewal. 2012. "Pengaruh Inflasi, Suku Bunga, Nilai Tukar Rupiah, dan Harga Emas Dunia Harga Minyak Dunia Terhadap Indeks Harga Saham Sektor Pertambangan di Indonesia". Jurnal Economia, Vol. Volume 8, No. Nomor 1., hlm.

Lawrence, S. S. 2013. "Pengaruh Variabel dan Harga Makroekonomi
Komoditas menuju indeks Harga

Saham Gabungan di Indonesia.". Jurnal Finesta

Fakultas Ekonomi Universitas Kristen Petra, Surabaya, Vol. 1, No. 2, hlm.

Liauw, J. S. 2011. "Analisis Pengaruh Tingkat Inflasi, Suku Bunga SBI dan Nilai Tukar Rupiah terhadap Indeks Harga Saham Gabungan (IHSG) di Bursa Efek Indonesia.". Jurnal eprint MDP., Vol., No., hlm: 1-8.

Mansur, M. 2009. "Pengaruh Suku Bunga SBI dan Nilai Tukar Dolar AS terhadap Indeks Bursa Efek Jakarta di Bursa Efek Jakarta". Jurnal Akuntansi dan Keuangan Universitas Padjadjaran, Vol., No., hlm.

Manurung, J., Jonni, dkk 2005. Teori dan Aplikasi Ekonometrik. Jakarta: PT Elex Media Komputindo.

Maryanti, S. 2009. "Analisis Pengaruh Suku Bunga terhadap Suku Bunga SBI dan Nilai Tukar Dolar terhadap Indeks Harga Saham Gabungan: Studi di Bursa Efek Jakarta.". Jurnal Ekonomi dan Bisnis, Vol. Vol. 1, No. (No. 1), hlm: 12-25.

Nugrayasa. 2013. "Jalan Panjang untuk Memacu Pertumbuhan dalam Investasi Sektor Pertanian. dari Sekretariat Kabinet Republik Indonesia". [diakses pada.

Rahmanely, N. 2007. "Pengaruh Perubahan Nilai Tukar dan Nilai Pasar Ekuitas (MVE) dari Pengembalian Saham Perusahaan yang terdaftar di Bursa Efek", Fakultas Ekonomi, Andalas University, Padang.

Safitri, R. d. S. K. 2014. "Dampak Suku Bunga, Inflasi, Nilai Tukar Dan PDB Terhadap Indeks Harga Saham Sektor Perkebunan.", Departemen Administrasi Bisnis 
Jakarta.

President University.,

Silim, L. 2013. "Pengaruh Variabel Makroekonomi pada Indeks Harga Saham Dikombinasikan dengan Bursa Efek Indonesia.". Jurnal Ilmiah Mahasiswa Ekonomi Bisnis, Vol. 2, No. 2, hlm.

Statistik BEI 2010.

http://www.idx.co.iddiakses pada 8 Oktober 2015.

Statistik BEI 2011. http://www.idx.co.id diakses pada 8 Oktober 2015.

Statistik BEI 2012. http://www.idx.co.id diakses pada 08 Oktober 2015.

Statistik BEI 2013. http://www.idx.co.id diakses pada 8 Oktober 2015.

Statistik BEI 2014. http://www.idx.co.id diakses pada 8 Oktober 2015.

Sukirno, S. 2002. Pengantar Teori Ekonomi Mikro. Jakarta: Raja Grafindo.

Thobarry, A. 2009. "Analisis Pengaruh Nilai Tukar, Tingkat Bunga, Tingkat Inflasi, dan Pertumbuhan PDB terhadap Sektor Properti Indeks Harga Saham (Studi Empiris pada Bursa Efek Indonesia Periode Pengamatan 20002008).", Magister Tesis

Manajemen, Program Pascasarjana,, Universitas Diponogoro., Semarang.

Wijayanti, A. J. 2013. "Pengaruh Beberapa Variabel Makroekonomi dan Indeks Pasar Capital Dunia Melawan Gerakan IHSG di Bursa Efek Indonesia.". Fakultas Ilmiah Ekonomi dan Bisnis., Vol., No., hlm. 